\title{
PENENTUAN DAERAH PRIORITAS PELAYANAN AKTA KELAHIRAN DENGAN METODE K-NN DAN K-MEANS
}

\author{
Ade Muchlis Maulana Anwari), Prihastuti Harsani2), Aries Maesya ${ }^{3)}$ \\ 1, 2 \& 3)Program Studi IImu Komputer, FMIPA, Universitas Pakuan, Bogor, Indonesia \\ ${ }^{2}$ Corresponding Author: prihastuti.harsani@unpak.ac.id
}

Article history: received 5 December 2019; revised 16 January 2020; accepted 22 January 2020

\begin{abstract}
Abstrak
Data Kependudukan adalah data perseorangan atau data agregat yang terstruktur sebagai hasil dari kegiatan Pendaftaran Penduduk dan Pencatatan Sipil. Akta Kelahiran adalah Akta Catatan Sipil hasil pencatatan peristiwa kelahiran seseorang bayi yang dilaporkan kelahirannya akan terdaftar dalam Kartu Keluarga dan diberi Nomor Induk Kependudukan (NIK) sebagai dasar untuk memperoleh pelayanan masyarakat lainnya. Dari jumlah pelaporan akta kelahiran yang terintegrasi Sistem Informasi Administrasi Kependudukan (SIAK) tahun 2018 yang berjumlah 570.637 terdapat 503.946 yang dilaporkan terlambat dan hanya 66.691 yang dilaporkan secara umum. Clustering merupakan metode yang digunakan untuk mengelompokan suatu data yang mirip dengan lainnya dalam satu kelompok ataupun ketidak miripan data terhadap kelompok lainnya. K-Nearest Neighbor adalah sebuah metode untuk melakukan klasifikasi terhadap objek berdasarkan data pembelajaran yang jaraknya paling dekat dengan data uji. k-means merupakan metode yang digunakan untuk membagi sejumlah objek ke dalam kelompok berdasarkan kategori-kategori yang ada dengan melihat titik tengah. Dalam praproses data mining, data dibersihkan dengan mengisi data yang kosong dengan data yang paling mendominasi, dan menyeleksi atribut dengan menggunakan metode information gain. Berdasarkan metode knearest neighbor untuk memprediksi keterlambatan pelaporan dan metode k-means untuk mengelompokan daerah yang menjadi prioritas pelayanan dengan 10.000 data kependudukan akta kelahiran tahun 2019 memiliki performa yang cukup baik menghasilkan prediksi dengan akurasi $74,00 \%$ dan dengan $K=2$ pada k-means menghasilkan index davies bouldin sebesar 1,179 .
\end{abstract}

Kata kunci: k-nearest neighbor, k-means, kependudukan, clustering, data mining.

\begin{abstract}
Population Data is individual data or aggregate data that is structured as a result of Population Registration and Civil Registration activities. Birth Certificate is a Civil Registration Deed as a result of recording the birth event of a baby whose birth is reported to be registered on the Family Card and given a Population Identification Number (NIK) as a basis for obtaining other community services. From the total number of integrated birth certificate reporting for the 2018 Population Administration Information System (SIAK) totaling 570,637 there were 503,946 reported late and only 66,691 were reported publicly. Clustering is a method used to classify data that is similar to others in one group or similar data to other groups. K-Nearest Neighbor is a method for classifying objects based on learning data that is the closest distance to the test data. $k$-means is a method used to divide a number of objects into groups based on existing categories by looking at the midpoint. In data mining preprocesses, data is cleaned by filling in the blank data with the most dominating data, and selecting attributes using the information gain method. Based on the k-nearest neighbor method to predict delays in reporting and the k-means method to classify priority areas of service with 10,000 birth certificate data on birth certificates in 2019 that have good enough performance to produce predictions with an accuracy of $74.00 \%$ and with $K=$ 2 on $k$-means produces a index davies bouldin of 1,179.
\end{abstract}


Keywords: $k$-nearest neighbor, k-means, population, clustering, data mining.

\section{Pendahuluan}

Data Kependudukan adalah data perseorangan atau data agregat yang terstruktur sebagai hasil dari kegiatan Pendaftaran Penduduk dan Pencatatan Sipil [1]. Administrasi Kependudukan adalah rangkaian kegiatan penataan dan penertiban dalam penerbitan dokumen dan Data Kependudukan melalui Pendaftaran Penduduk, Pencatatan Sipil, pengelolaan informasi Administrasi Kependudukan serta pendayagunaan hasilnya untuk pelayanan publik dan pembangunan sektor lain.

Pencatatan Sipil adalah pencatatan Peristiwa Penting yang dialami oleh seseorang dalam register Pencatatan Sipil pada Dinas Kependudukan dan Pencatatan Sipil Kabupaten atau Kota atau Unit Pelaksana Teknis Dinas Kependudukan dan Pencatatan Sipil. Pelayanan Pencatatan Sipil terdiri atas kelahiran, lahir mati, perkawinan, pembatalan perkawinan, perceraian, pembatalan perceraian, kematian, pengangkatan anak, pengesahan anak, perubahan nama, perubahan status kewarganegaraan, Peristiwa penting lainnya, pembetulan akta, pembatalan akta, pengakuan anak.

Akta Kelahiran adalah Akta Catatan Sipil hasil pencatatan peristiwa kelahiran seseorang bayi yang dilaporkan kelahirannya akan terdaftar dalam Kartu Keluarga dan diberi Nomor Induk Kependudukan (NIK) sebagai dasar untuk memperoleh pelayanan masyarakat lainnya. Dalam penginputan data Akta Kelahiran terdapat klasifikasi menurut waktu pelaporan, yaitu pelaporan yang lebih dari 60 hari dari tanggal kelahiran maka di kategorikan sebagai pelaporan yang terlambat, sementara pelaporan yang di lakukan sebelum 60 hari dari tanggal kelahiran maka dikategorikan sebagai pelaporan umum. Di dalam Pelaporan Akta Kelahiran yang mendominasi adalah pelaporan yang terlambat.

Data mining merupakan proses penggalian informasi dalam basis data yang besar dan proses klasifikasi dan otomatisasi kasus berdasarkan pola data yang diperoleh dari data set. Data mining juga didefinisikan sebagai satu set teknik yang digunakan secara otomatis untuk mengeksplorasi secara menyeluruh dan membawa ke permukaan relasi-relasi yang kompleks pada set data yang sangat besar [2].

Menurut Badan Pusat Statistik (BPS) Kabupaten Bogor tahun 2018 mencapai 5.840.907 jiwa [3]. Berdasarkan Sistem Informasi Administrasi Kependudukan (SIAK) tahun 2018 yang berjumlah 570.637 terdapat 503.946 yang dilaporkan terlambat dan hanya 66.691 yang dilaporkan secara umum. Penelitian ini akan menggunakan metode K-Nearest Neighbor untuk memprediksi keterlambatan pelaporan akta kelahiran, setelah data diprediksi maka digunakan metode K-Means [4] untuk pengelompokan daerah yang akan menjadi prioritas pelayanan. Sehingga diharapkan pelayanan ataupun sosialisasi dapat dilakukan pada daerah yang tepat sasaran.

K-Nearest Neighbor (K-NN) adalah metode melakukan klasifikasi terhadap objek berdasarkan data pembelajaran yang jaraknya paling dekat dengan objek tersebut. Metode ini bertujuan untuk mengklasifikasikan objek baru berdasarkan atribut dan training sample. Diberikan suatu titik query, selanjutnya akan ditemukan sejumlah $\mathrm{K}$ objek atau titik training yang paling dekat dengan titik query. Nilai prediksi dari query akan ditentukan berdasarkan klasifikasi tetanggaan. Dalam meningkatkan hasil evaluasi Clustering Davis-Bouldin Index [5] dengan Penentuan Titik Pusat Cluster awal algoritma K-Mean untuk mendukung data mining adalah metode K-Nearest Neighbor dan untuk memastikan dapat menggunakan Certainty Factor [6] yang merupakan penggabungan 2 metode dimana hasil klasifikasi dari metode K-Nearest Neighbor akan diberi nilai kepastian oleh metode Certainty Factor sehingga menghasilkan suatu penentuan Pelayanan Kelahiran.

Peraturan Presiden (PERPRES) Nomor 25 Tahun 2008 Persyaratan dan Tata Cara Pendaftaran Penduduk [7] dan Pencatatan Sipil dan Undang-Undang Administrasi Kependudukan (Adminduk) mengamanatkan agar data kependudukan digunakan untuk semua urusan, di antaranya untuk pelayanan publik dan perencanaan pembangunan. Akan tetapi, pemanfaatan data kependudukan perlu mengutamakan segi keamanan [8] untuk melindungi kerahasiaan data pribadi penduduk. 


\section{Metode Penelitian}

Metode yang digunakan untuk Penelitian ini adalah tahapan dari data mining yaitu Knowledge Discovery and Data Mining (KDD). Gambaran metode ini dapat dilihat dalam Gambar 1.

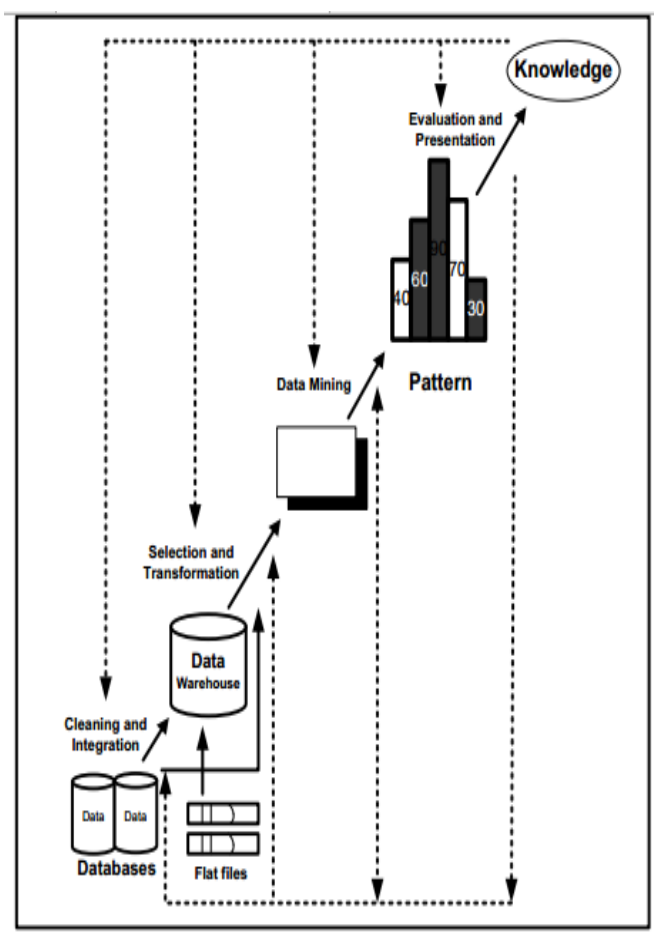

Gambar 1. Tahap-tahap data mining

Tahap Pembersihan data adalah suatu proses awal data mining yaitu menghilangkan data noise, contohnya seperti atribut dengan nilai kosong. Data awal diperoleh dari Dinas Kependudukan dan Pencatatan Sipil Kabupaten Bogor sebanyak 10.000 data. Dalam dataset kependudukan yang digunakan terdapat beberapa atribut yang memiliki nilai kosong, hal ini jika tidak dihilangkan akan mengganggu proses data mining.

Proses seleksi atribut merupakan proses untuk mengidentifikasi dan menghilangkan atribut dengan nilai yang tidak relevan atau berlebihan. Proses seleksi atribut dilakukan dengan menggunakan Information Gain yang merupakan suatu langkah dalam metode C4.5.

Proses transformasi data dilakukan karena dalam beberapa metode data mining membutuhkan format input data yang sesuai untuk di proses. Data atribut di transformasi kedalam data numerik. Pada tahapan ini dilakukan konversi data yaitu mengubah data dari tipe data nominal ke dalam bentuk numeric. Proses konversi dilakukan karena untuk klasifikasi menggunakan algoritme $\mathrm{KNN}$, atribut data input harus bersifat numeric yang dapat diproses, sedangkan data yang didapat masih dalam bentuk nominal [5].

Tahap proses mining Merupakan suatu proses untuk menggali pengetahuan yang tersembunyi dari kumpulan data. Untuk proses mining digunakan metode K-Nearest Neighbor (KNN), dan K-Means. Dimana awalnya data diklasifikasi terlebih dahulu menggunakan KNN, kemudian atribut hasil klasifikasi tersebut dijadikan atribut tambahan untuk proses Kmeans. Proses dilakukan dengan membagi data menjadi data training dan data testing.

Proses evaluasi pola dilakukan setelah proses mining, dilakukan proses evaluasi untuk mengetahui pola pengetahuan yang ditemukan. Untuk mengevaluasi metode KNN digunakan 
perhitungan akurasi untuk melihat seberapa besar persentase kebenaran KNN. Sementara untuk mengevaluasi pengelompokan K-Means di lakukan dengan Index Davies Bouldin (IDB).

Proses presentasi pengetahuan adalah proses akhir data mining yaitu sebuah visualisasi pengetahuan tentang metode yang digunakan. Untuk visualisasinya adalah berupa grafik dan di dalam sistem berbasis web.

Alat yang digunakan pada penelitian ini yaitu laptop dan flashdisk, untuk perangkat lunak yang digunakan adalah Xampp, dan Toad for Oracle 12 dan untuk bahan yang digunakan pada penelitian ini adalah Data kependudukan kabupaten Bogor.

\section{Hasil dan Pembahasan}

Tahapan penelitian untuk melakukan prediksi keterlambatan pelaporan akta kelahiran menggunakan K-NN dan pengelompokan daerah prioritas pelayanan menggunakan K-means dapat dilihat pada Gambar 2.

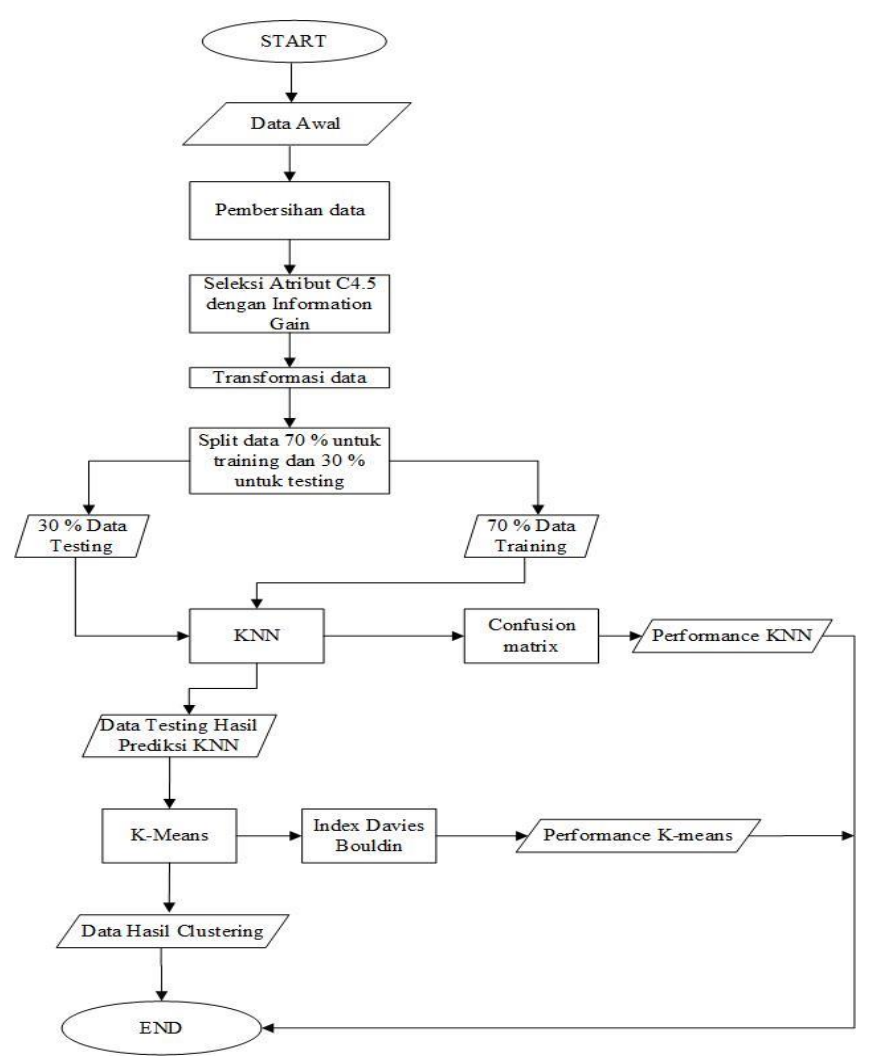

Gambar 2. Tahapan penelitian

untuk mendukung penelitian ini dibangun sebuah aplikasi berbasis website untuk melakukan proses tahap penelitian pada Gambar 3 dan Gambar 4.

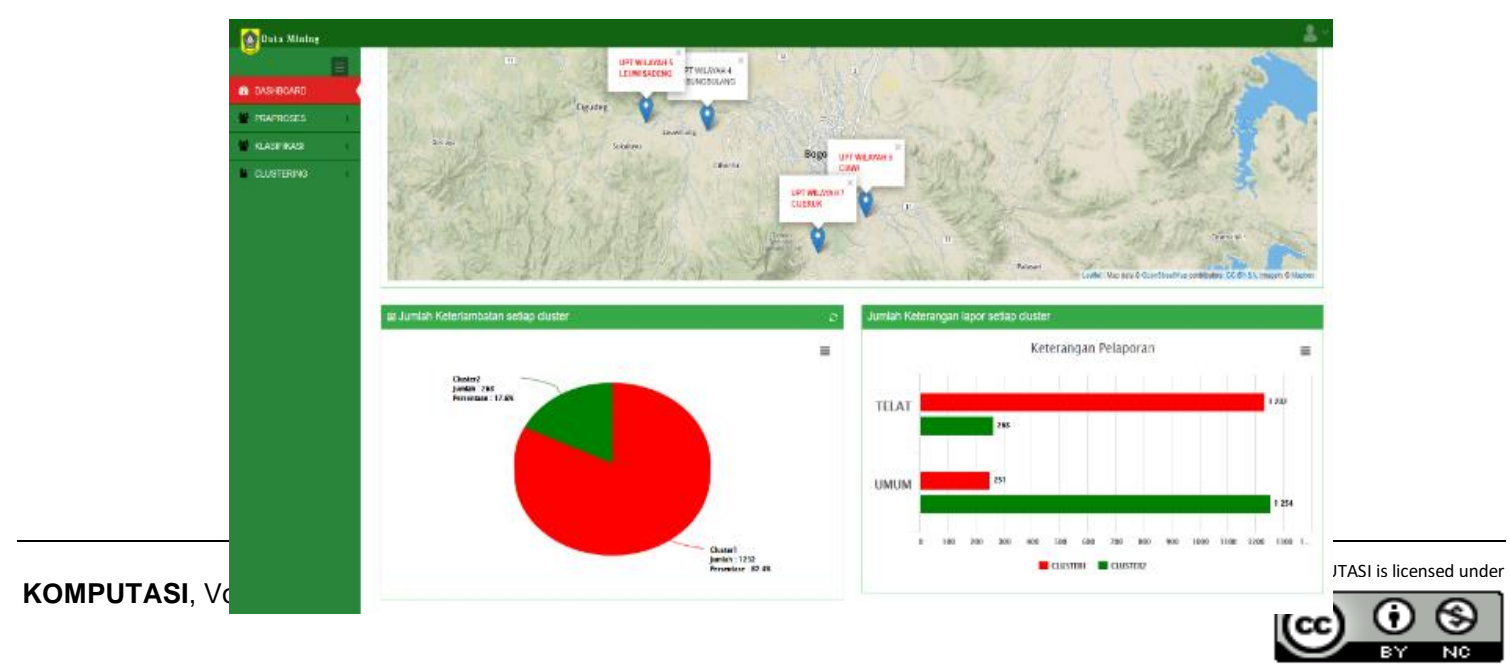




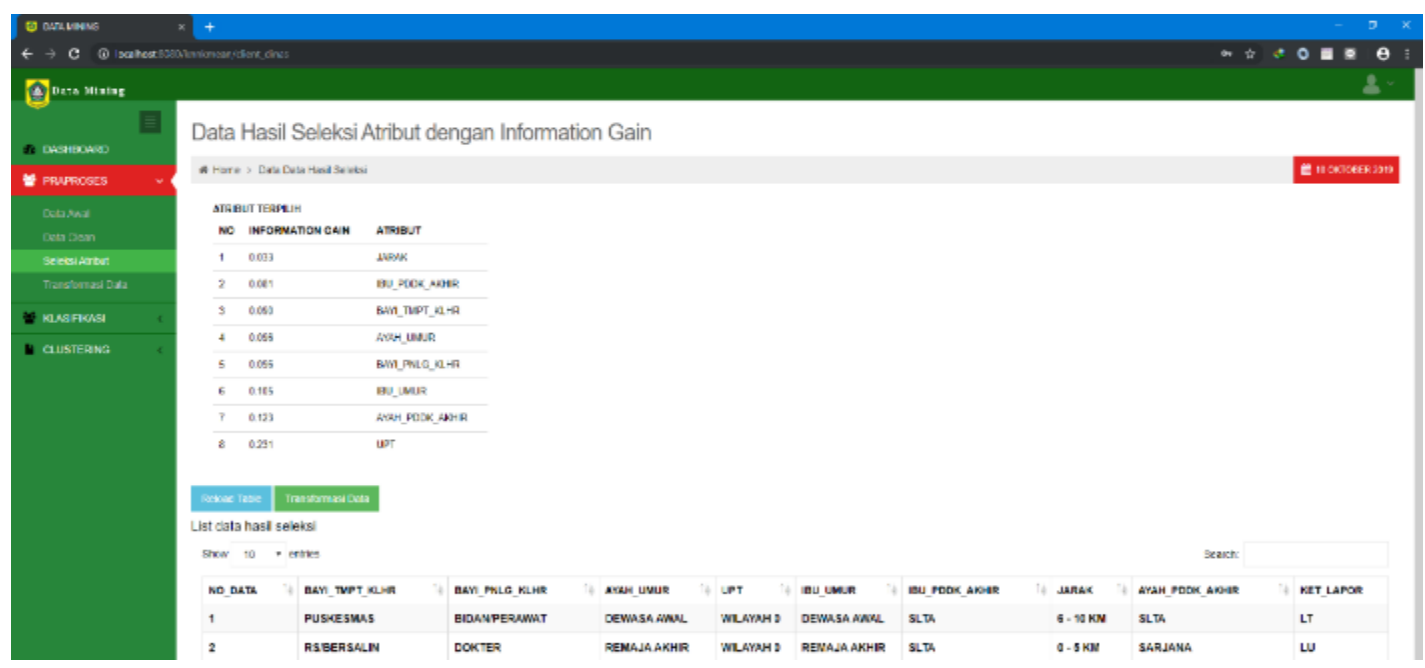

Gambar 4. Tampilan halaman seleksi atribut

Dalam seleksi atribut menggunakan information gain atribut yang berjumlah 29 atribut, diseleksi menjadi 9 atribut. Atribut yang terpilih adalah Jarak, Ibu Pendidikan Akhir, Bayi Tempat Kelahiran, Bayi Penolong Kelahiran, Ayah Umur, Ibu Umur, Ayah Pendidikan Akhir, Daerah UPT. Dan 1 atribut keterangan pelaporan yang akan di prediksi. Setelah data di pecah menjadi 7000 data training dan 3000 data testing, dalam Proses KNN dengan 3000 data testing dan $\mathrm{K}=11$ yang digunakan menghasilkan True Positive (TP) berjumlah 1091, False Negative (FN) berjumlah 404, False Positive (FP) berjumlah 376 dan True Negative (TN) berjumlah 1129. Hasil prediksi ditunjukan dalam Gambar 5.

\section{Data Hasil prediksi KNN \\ * Home > Data Hasil prediksi KNN \\ TOTAL DATA : 3000 \\ FALSE POSITIVE (FP) : 376 \\ FALSE NEGATIVE (FN) : 404 \\ TRUE POSITIVE (TP) : 1091 \\ TRUE NEGATIVE (TN): 1129}

\section{Gambar 5. Hasil prediksi K-NN}

Data yang telah selesai di prediksi akan diproses kembali menggunakan metode K-Means. Dalam Proses $\mathrm{K}$-means cluster ditentukan dari nilai $\mathrm{K}$ dengan IDB terkecil yaitu $\mathrm{K}=3$. Selain dari $\mathrm{K}=3$. Dikarenakan untuk clusterisasinya hanya ada Prioritas dan tidak Prioritas maka akan diujicoba juga $\mathrm{K}=2$. Untuk $\mathrm{K}=3$ Proses iterasi berakhir pada iterasi ke 13 posisi cluster tidak mengalami perubahan, maka iterasi dihentikan dan hasil akhirnya diperoleh ditunjukan dalam Tabel 1

Tabel 1. Perbandingan hasil cluster $\mathrm{K}=3$

\begin{tabular}{lccc}
\hline Data & Cluster 1 & Cluster 2 & Cluster 3 \\
\hline Jumlah data & 720 & 1517 & 763 \\
\hline $\begin{array}{l}\text { Penentuan Daerah Prioritas Pelayanan Akta Kelahiran dengan Metode K-NN dan K-Means } \\
\text { (Ade Muchlis Maulana Anwar, Prihastuti Harsani, Aries Maesya) }\end{array}$ & komputas is licensed under \\
\hline
\end{tabular}


Jumlah lapor telat 566

Jumlah lapor umum

Pendidikan akhir ayah SD/SMP yang melapor telat

Pendidikan akhir ibu tidak sekolah yang melapor telat

Pendidikan akhir ibu SD/SMP yang melapor telat

0

0

$\begin{array}{cc}263 & 666 \\ 1254 & 97 \\ 0 & 5 \\ 0 & 476 \\ 0 & 6 \\ 0 & 519\end{array}$

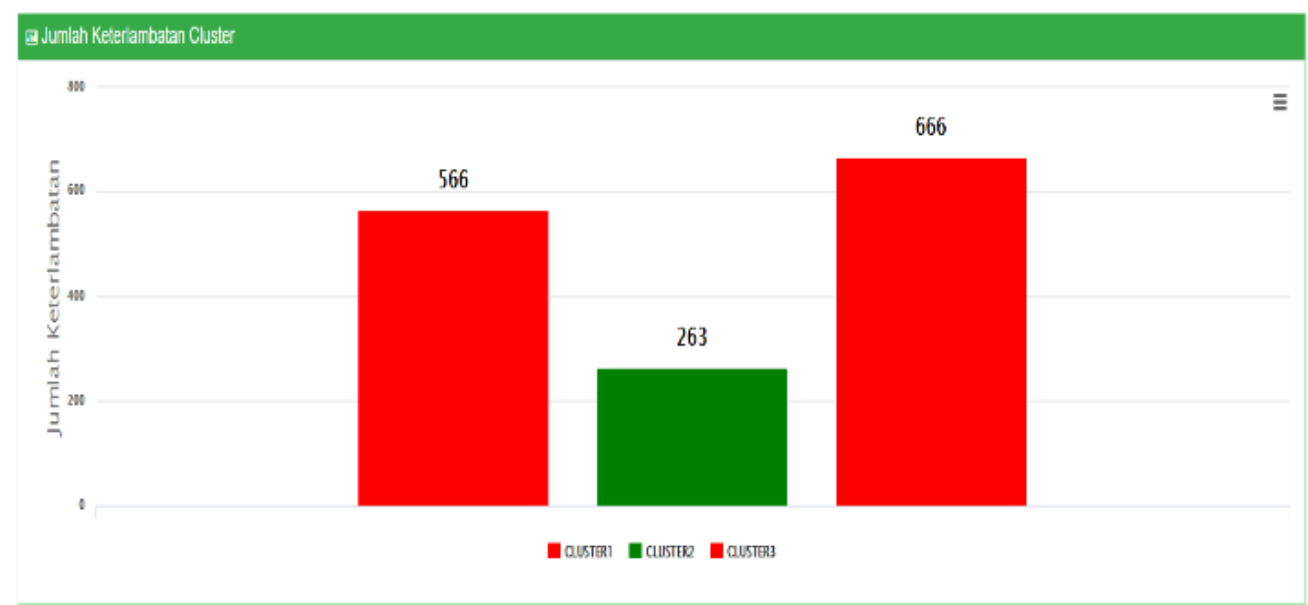

Gambar 6. Grafik cluster $\mathrm{K}=3$ total keterlambatan berdasarkan cluster
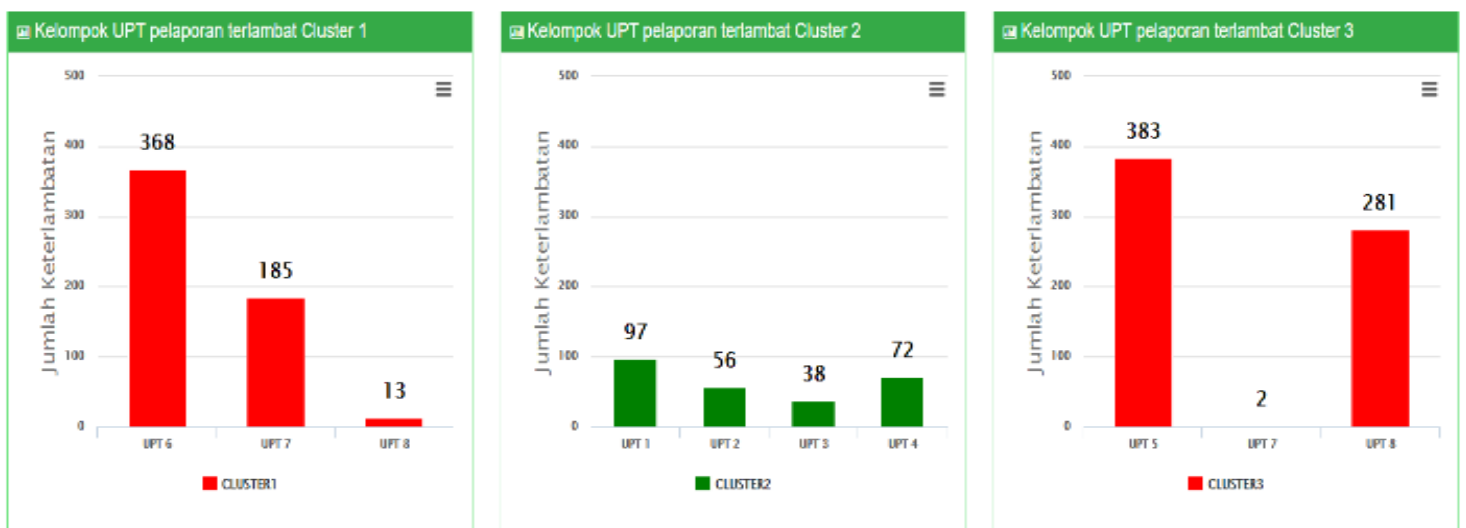

Gambar 7. Grafik cluster $\mathrm{K}=3$ total keterlambatan berdasarkan cluster dan UPT

Untuk $\mathrm{K}=2$ Proses iterasi berakhir pada iterasi ke 4 posisi cluster tidak mengalami perubahan, maka iterasi dihentikan dan hasil akhirnya diperoleh data pada Tabel 2

Tabel 2. Perbandingan hasil cluster $\mathrm{K}=2$

\begin{tabular}{lcc}
\hline Data & Cluster 1 & Cluster 2 \\
\hline Jumlah data & 1483 & 1517 \\
Jumlah lapor telat & 1232 & 263 \\
Jumlah lapor umum & 251 & 1254 \\
Pendidikan akhir ayah tidak sekolah yang melapor telat & 6 & 0 \\
Pendidikan akhir ayah SD/SMP yang melapor telat & 495 & 0 \\
Pendidikan akhir ibu tidak sekolah yang melapor telat & 6 & 0 \\
Pendidikan akhir ibu SD/SMP yang melapor telat & 550 & 0 \\
\hline
\end{tabular}




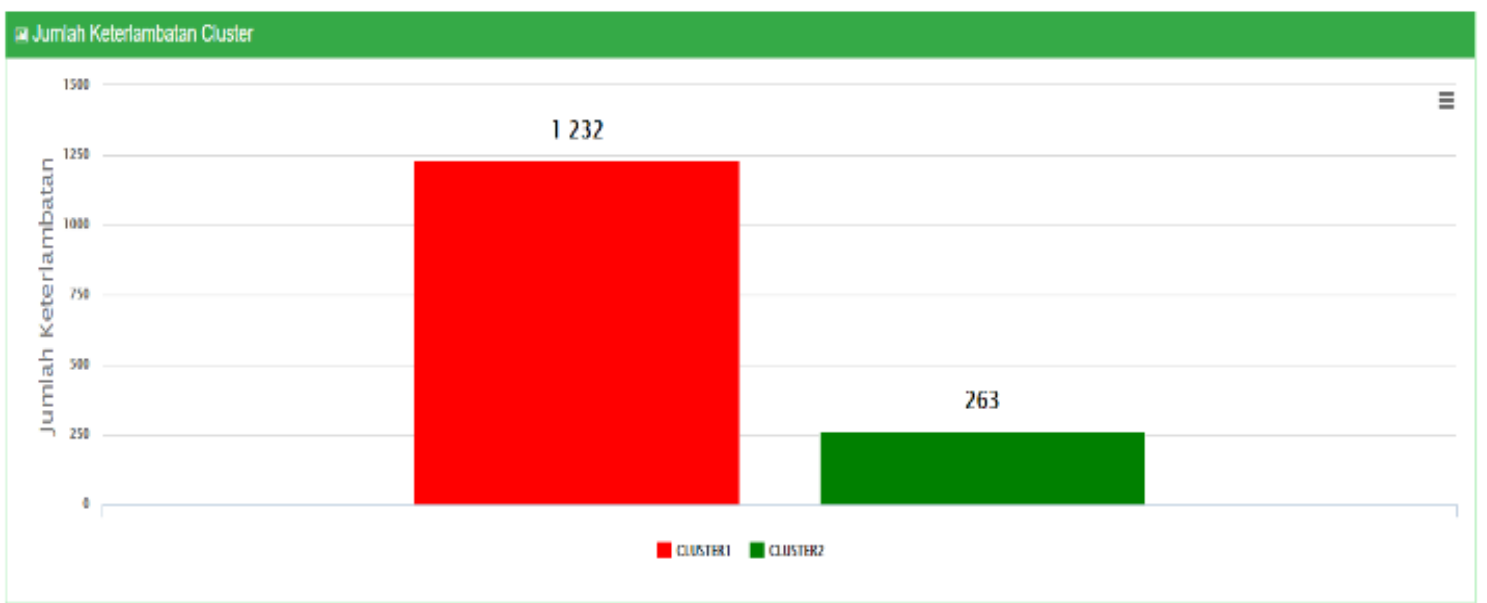

Gambar 8. Grafik cluster $\mathrm{K}=2$ total keterlambatan berdasarkan cluster

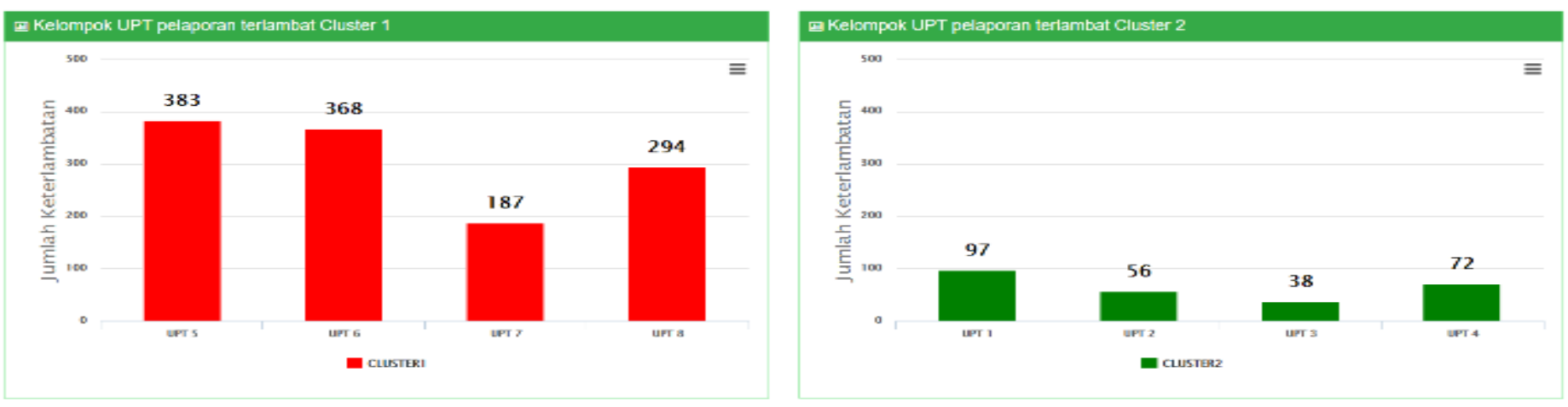

Gambar 9. Grafik cluster K = 2 total keterlambatan berdasarkan cluster dan UPT

Untuk $\mathrm{K}=3$ berdasarkan gambar 10 dan gambar 11 di atas maka dapat disimpulkan cluster yang menjadi prioritas adalah cluster 1 atau 3 dengan UPT wilayah 5,6,7,8 dengan jumlah keterlambatan pelaporan pada cluster 1 sebanyak 566 data dan cluster 3 sebanyak 666 data. Untuk $\mathrm{K}=2$ berdasarkan Gambar 12 dan Gambar 13, maka dapat disimpulkan cluster yang menjadi prioritas adalah cluster 1 dengan UPT wilayah 5,6,7,8. Dengan jumlah keterlambatan 1232 data.

Untuk mengevaluasi metode KNN yang digunakan, dilakukan proses perhitungan Confusion Matrix. Dimana positif adalah LT dan negative adalah LU. Nilai representasi untuk perhitungan Confusion Matrix adalah untuk True Positive (TP) berjumlah 1091, False Negative (FN) berjumlah 404, False Positive (FP) berjumlah 376 dan True Negative (TN) berjumlah 1129. 
Menghitung Accuracy yang menunjukkan berapa persen data yang benar diprediksi LT dan LU dari keseluruhan data.

$$
\frac{(T P+T N)}{(T P+T N+F N)} \times 100 \%=\left(\frac{1091=1129}{1091+1129+376+404}\right) \times 100 \%=74 \%
$$

Menghitung Precision yang menunjukkan berapa persen data yang benar LT dari keseluruhan data yang diprediksi LT.

$$
\frac{T P}{(F P+T P)} \times 100 \%=\frac{1091}{(376+1091)} \times 100 \%=74,37 \%
$$

Menghitung Recall yang menunjukkan berapa persen data yang diprediksi LT dibandingkan dengan data yang sebenarnya LT.

$$
\frac{T P}{(F N+T P)} \times 100 \%=\frac{1091}{(404+1091)} \times 100 \%=72,98 \%
$$

\section{Data Hasil prediksi KNN}

* Home > Data Hasil prediksi KNN

TOTAL DATA : 3000

FALSE POSITIVE (FP) : 376

FALSE NEGATIVE (FN) : 404

TRUE POSITIVE (TP) : 1091

TRUE NEGATIVE (TN): 1129
ACCURACY $74.00 \%$

PRECISION : $74.37 \%$

RECALL : $72.98 \%$

\section{Gambar 10. Tampilan hasil Confussion matrix}

Perhitungan Index Davies Bouldin (IDB) pada sistem menggunakan $\mathrm{K}=2$, untuk mencari IDB adalah dengan mencari ratio tertinggi dari rasio untuk $\mathrm{K}=2$ yaitu 1,179 . Semakin kecil nilai Index Davies Bouldin (IDB) yang diperoleh (non-negatif $>=0$ ), maka semakin baik cluster yang diperoleh dari pengelompokan menggunakan algoritma clustering (Bates \& Kalita 2016). Nilai SSW diperoleh dari perhitungan jarak setiap data terhadap titik pusat cluster akhir menggunakan Euclidean Distance [6].

$$
\begin{aligned}
& K=2 \\
& S S W 1=3,447 \\
& S S W 2=2,143
\end{aligned}
$$

Selanjutnya dilakukan perhitungan SSB dengan menghitung jarak antar titik pusat cluster dari setiap cluster. Hasil dari SSB adalah

Jarak cluster 1 ke cluster 1, SSB1, $1=0$

Jarak cluster 1 ke cluster 2, SSB1, $2=4,741$

Jarak cluster 2 ke cluster 1, SSB2, $1=4,741$

Jarak cluster 2 ke cluster 2, SSB2,2 $=0$

\begin{tabular}{|c|c|c|c|c|}
\hline \multirow[t]{2}{*}{ Rasio } & \multicolumn{2}{|c|}{ data ke i } & \multirow[t]{2}{*}{ R-max } & \multirow[t]{2}{*}{ IDB } \\
\hline & 1 & 2 & & \\
\hline 1 & 0 & 1,179 & 1,179 & 1,179 \\
\hline 2 & 1,179 & 0 & 1,179 & \\
\hline
\end{tabular}

Kemudian melakukan perhitungan ratio, dikarenakan data hanya di uji dengan 2 cluster, maka ratio di hitung hanya jarak cluster 1 ke cluster 2 .

$$
\begin{gathered}
\text { Rasio } 11=\left(\begin{array}{c}
\text { SSW } 1+\mathrm{SSW} 1) / \mathrm{SSB} 1,1 \\
(3,447+3,447) / 0=0
\end{array}\right. \\
\text { Rasio } 12=(\mathrm{SSW} 1+\mathrm{SSW} 2) / \mathrm{SSB} 1,2 \\
(3,447+2,143) / 4,741=1,179 . \\
\text { Rasio } 21=\left(\begin{array}{c}
(\mathrm{SSW} 2+\mathrm{SSW} 1) / \mathrm{SSB} 2,1 \\
(2,143+3,447) / 4,741=1,179
\end{array}\right. \\
\text { Rasio } 22=(\mathrm{SSW} 2+\mathrm{SSW} 2) / \mathrm{SSB} 2,2
\end{gathered}
$$

$(2,143+2,143) / 0=0$

Tabel 3. Nilai rasio setiap cluster $\mathrm{K}=2$ 


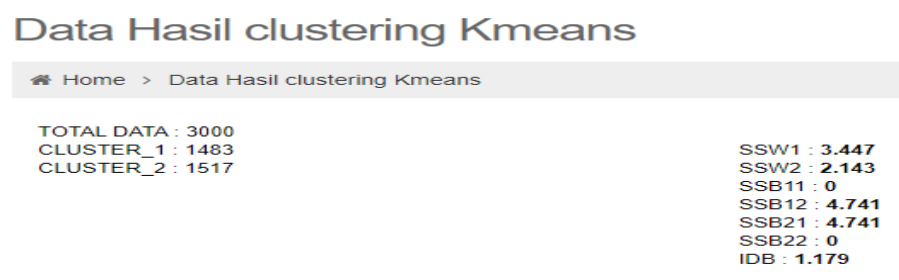

$\mathrm{K}=3$

Gambar 11. Tampilan hasil Index davies bouldin $\mathrm{K}=2$

$\mathrm{SSW} 1=2,043$

SSW2 $=2,143$

SSW3 $=2,661$

Selanjutnya dilakukan perhitungan SSB dengan menghitung jarak antar titik pusat cluster dari setiap cluster. Hasil dari SSB adalah

Jarak cluster 1 ke cluster $1, \mathrm{SSB} 1,1=0$

Jarak cluster 1 ke cluster $2, \mathrm{SSB} 1,2=4,107$

Jarak cluster 1 ke cluster 3, SSB1, $3=4,963$

Jarak cluster 2 ke cluster 1, SSB2, $1=4,107$

Jarak cluster 2 ke cluster 2, SSB2, $2=0$

Jarak cluster 2 ke cluster 3, SSB2, $3=6,303$

Jarak cluster 3 ke cluster 1 , SSB3, $1=4,963$

Jarak cluster 3 ke cluster 2, SSB3, $2=6,303$

Jarak cluster 3 ke cluster 3 , SSB3, $3=0$

Kemudian melakukan perhitungan ratio, dikarenakan data hanya di uji dengan 2 cluster, maka ratio di hitung hanya jarak cluster 1 ke cluster 2 .

$$
\begin{aligned}
& \text { Rasio } 11=(\mathrm{SSW} 1+\mathrm{SSW} 1) / \mathrm{SSB} 1,1 \\
& (2,043+2,043) / 0=0 \\
& \text { Rasio } 12=(\mathrm{SSW} 1+\mathrm{SSW} 2) / \mathrm{SSB} 1,2 \\
& (2,043+2,143) / 4,107=1,0192 . \\
& \text { Rasio } 13=(\text { SSW } 1+\text { SSW3 }) / \text { SSB1, } 3 \\
& (2.043+2,661) / 4,963=0,9478 \text {. } \\
& \text { Rasio } 21=(\text { SSW2 }+ \text { SSW1) } / \text { SSB2,1 } \\
& (2,143+2,043) / 4,107=1,0192 \\
& \text { Rasio } 22=(\text { SSW2 }+ \text { SSW2 }) / \text { SSB2,2 } \\
& (2,143+2,143) / 0=0 \\
& \text { Rasio } 23=(\text { SSW } 2+\text { SSW } 3) / \text { SSB2, } 3 \\
& (2,143+2,661) / 6,303=0,7622 \\
& \text { Rasio } 31=(\text { SSW3 }+ \text { SSW1 }) / \text { SSB3,1 } \\
& (2,661+2,043) / 4,963=0,9478 \\
& \text { Rasio } 32=(\text { SSW3 }+ \text { SSW2 }) / \text { SSB3, } 2 \\
& (2,661+2,143) / 6,303=0,7622 \\
& \text { Rasio } 33=(\text { SSW3 }+ \text { SSW3 }) / \text { SSB3,3 } \\
& (2,661+2,661) / 0=0
\end{aligned}
$$

Tabel 4. Nilai rasio setiap cluster $\mathrm{K}=3$

\begin{tabular}{rrrrrr}
\hline Rasio & \multicolumn{3}{c}{ data ke i } & R-max & IDB \\
\cline { 2 - 4 } & 1 & 2 & 3 & & \\
\hline 1 & 0 & 1,0192 & 0,9478 & 1,0192 & 0,996 \\
\hline 2 & 1,0192 & 0 & 0,7622 & 1,0192 & \\
\hline
\end{tabular}




$\begin{array}{lllll}3 & 0,9478 & 0,7622 & 0 & 0,9478\end{array}$

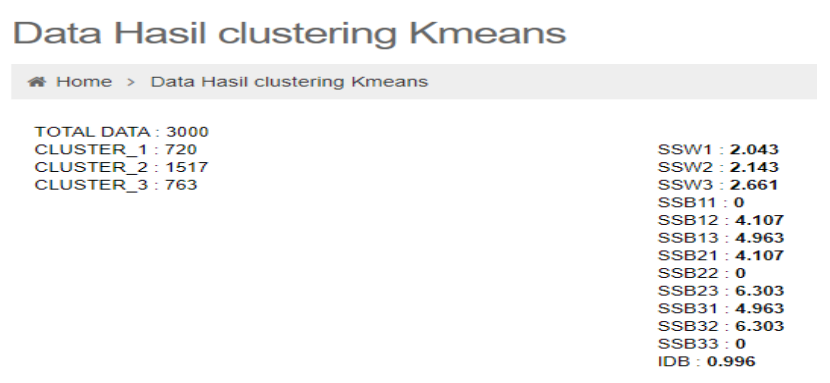

Gambar 12. Tampilan hasil Index davies bouldin $\mathrm{K}=3$

\section{Kesimpulan}

Dari data kependudukan yang dilakukan proses prediksi dengan metode k-nearest neighbor menghasilkan akurasi $74,00 \%$, dan pengelompokan denhan metode $\mathrm{k}$ - index davies bouldin sebesar 1,179 . Berdasarkan keterlambatan pelaporan yang paling mendominasi untuk $\mathrm{K}=2$ adalah cluster 1 dengan jumlah 1483 dengan UPT 5,6,7,8. Maka untuk $\mathrm{K}=2$ dapat menjadikan cluster 1 sebagai prioritas. Untuk $\mathrm{K}=3$ yang paling mendominasi keterlambatan pelaporan adalah cluster 1 dan cluster 3 dengan jumlah cluster 1 sebanyak 720 data, dan cluster 3 sebanyak 763 dengan UPT 5,6,7,8.

Referensi

[1] Peraturan Presiden Nomor 96, Persyaratan Dan Tata Cara Pendaftaran Penduduk Dan Pencatatan Sipil, Jakarta: Sekretariat Negara, 2018.

[2] Z. Aras dan Sarjono, "Analisis Data Mining Untuk Menentukan Kelompok Prioritas Penerima Bantuan Bedah Rumah Menggunakan Metode Clustering K-Means," Jurnal Manajemen Sistem Informasi, vol. Vol. 1, no. STIKOM Dinamika Bangsa Jambi, p. No. 2, 2016.

[3] Badan Pusat Statistik, "Penduduk Kabupaten Bogor Tahun 2018-2019. https://bogorkab.bps.go.id," diakses pada 01 Mei 2019, Bogor, 2019.

[4] F. Kusumaningrum, "Klasifikasi Kemunculan Titik Panas Pada Lahan Gambut Di Sumatera Dan Kalimantan Menggunakan Algoritme K-Nearest Neighbor," Skripsi. Jurusan IImu Komputer FMIPA IPB, Bogor, 2015.

[5] Sitompul and B. J. Dehotman, "Meningkatan Hasil Evaluasi Clustering Davies-Bouldin Index Dengan Penentuan Titik Pusat Cluster Awal Algoritma K-Mean," Tesis. Fakultas IImu Komputer Dan Teknologi Informasi. Universitas Sumatera Utara, Medan, 2018.

[6] Gesa Rizky N, Sri Setyaningsih, Asep Saepulrohman, "PERANCANGAN SISTEM PAKAR PENENTUAN USAHATANI BUDI DAYA PADI MENGGUNAKAN METODE CERTAINTY FACTOR BERBASIS ANDROID," Komputasi: Jurnal IImiah IImu Komputer dan Matematika, vol. 16, no. 2, pp. 289-295, 2019.

[7] Peraturan Presiden Nomor 25, Persyaratan dan Tata Cara pendaftaran Penduduk dan Pencatatan Sipil, Jakarta: Sekretariat Negara, 2008.

[8] Asep Saepulrohman, "Dekoding Sindrom Kode Linear Gilbert-Varshamov Biner dengan Jarak Minimum 15," Komputasi: Jurnal IImiah Ilmu Komputer dan Matematika, vol. 18, no. 2, pp. 164-171, 2018. 